\title{
ON NEMATODE-DESTROYING FUNGI IN FINLAND
}

\author{
Anna-LiIsa Ruokola \& Arvi Salonen \\ Department of Plant Pathology, University of Helsinki
}

Received March 24, 1967

On the initiative of the Department of Dermathology, the Central Hospital of the University of Helsinki material was collected in summer 1966 in the countryside for the purpose of investigating whether the Finnish "sauna" (bath house) was a possible spreading point for the chromoblastomycosis-disease. During the investigation it was discovered that many of the specimens were infected by nematodes. Closer inspection revealed an interesting nematode-destroying fungal group which has not been recognized previously in Finland. Since it is also of significance in the biological control of nematodes (cf. Linford \& YAP 1939; SopRUnOv \& TENDETNIK 1960; PÄÄSUKE 1962; Duthoit \& GoDFREY 1963) it was made the subject of a separate survey.

The investigation material consisting of 60 specimens had been collected from different parts of Finland. From each "sauna" 2-4 specimens were taken, in the form of thin shavings from the wooden surface of the floor, the steps, and the platforms (with benches). The shavings were strewn on modified Czapek's and corn-meal agar plates. The cultures were kept in the laboratory, at a temperature of $21-22^{\circ} \mathrm{C}$. The first observations on the growth of the fungi were made after 14 days and subsequently at weekly intervals during about two months. The great number of nematodes originating from the specimens affected adversely the growing of the fungi in the cultures, in fact in some plates there was no aerial mycelium to be found. Consequently the mycelium below the surface of the nutrient agar was also investigated. The Difco rice-meal agar was used as nutrient medium for the pure cultures. The other nutrient agars used in the investigations were: Czapek's agar, modified: $\mathrm{NaNO}_{3} 3.0 \mathrm{~g}, \mathrm{~K}_{2} \mathrm{HPO}_{4} 1.0 \mathrm{~g}, \mathrm{MgSO}_{4} \times 7 \mathrm{H}_{2} \mathrm{O} 0.01 \mathrm{~g}$, glucose $5.0 \mathrm{~g}$, agar $15.0 \mathrm{~g}$ and $\mathrm{H}_{2} \mathrm{O} 1000 \mathrm{ccm}$ and maize-meal agar $(0.5 \%$ glucose $)$. For the determination of fungal 
species 50 spores from each isolate were measured. The biogeographical province and the parish as well as the number of isolates indicate the places of discovery of the isolated fungi.

The abbreviations of the biogeographical provinces of Finland used in this work, are the following: $T a=$ Tavastia australis; $S a=$ Savonia australis; $K b=$ Karelia borealis; $S b=$ Savonia borealis; $S t=$ Satakunta.

All the fungus species discovered in this investigation belong to the Fungi imperfecti.

Nematoctonus concurrens Drechsler, Mycol. 41: 369-387, 1949.

Delicate, arachnoid hyphae of the fungus occurred only scantily on the surface of the nutrient agar. The mycelium was mostly submerged, studded with clampconnections, $2.0-3.5 \mu$ in diam. The numerous conidia which had formed at the tips of the short, spike-like sterigmata of the hyphae were elongated-ellipsoidal or cylindrical, straight or slightly curved, tapered at the basal end and broadly rounded at the distal end, $11.9-21.0 \times 3.9-5.6 \mu$ in diam. (Fig. 1, A-B). In addition, short, nematode-capturing outgrowths were observed on the hyphae (Fig. 1, C). These were

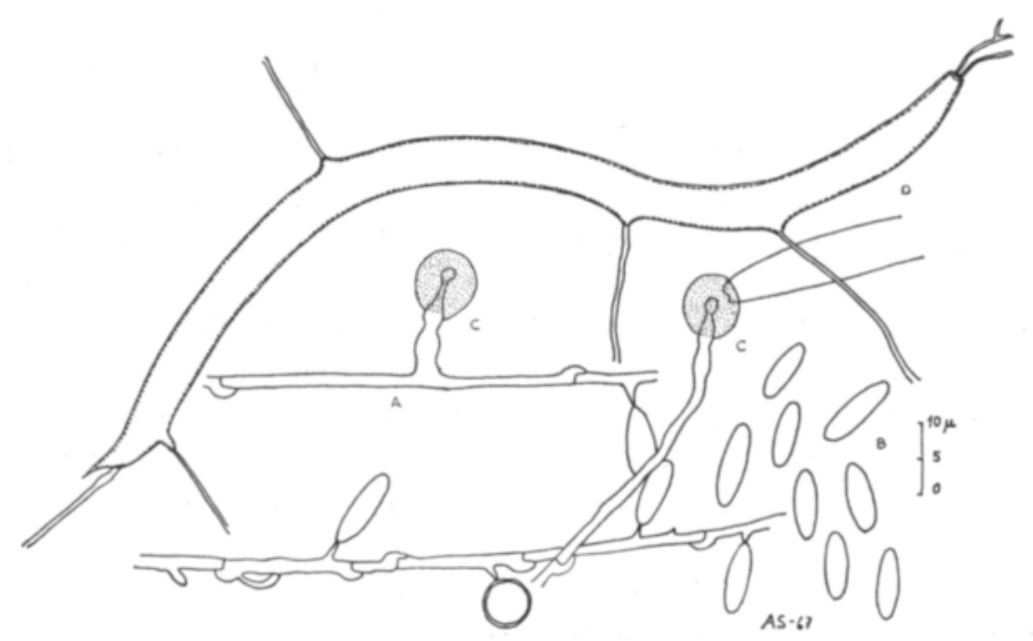

Fig. 1. Nematoctonus concurrens Drechsler. A-B. Fertile mycelium studded with clamp-connections. C. Predacious organs with adhesive tips. D. Fungus-destroyed nematode. 50-day old Czapekś agar (glucose $0,5 \%$ ) culture.

constricted in the middle, and secreted a viscous fluid. In the nutrient medium were found several nematodes attached from their mouths to these adhesive organs; from the nematodes grew an abundance of hyphae (Fig. 1, D).

Ta. Nastola 1. - Sa. Joutseno 2; Luumäki 3.

DRECHSLER (1949) found this fungus in the U.S.A. in decaying leaves and stems of Bromus secalinus. He established that it destroyed Panagrolaimus subelongatusand Ditylenchus sp.- nematodes. 
Nematoctonus leiosporus Drechsler, Phytopath. 31: 779-780, 1941.

The occurrence of the fungus was established from the specimens taken from nutrient agar. The mycelium was submerged, arachnoid, provided with clampconnections, $1.4-3.0 \mu$ in diam. On the erect, spike-like sterigmata of the hyphae there was an abundance of conidia, unicellular, digitiform, tapering regularly upward,
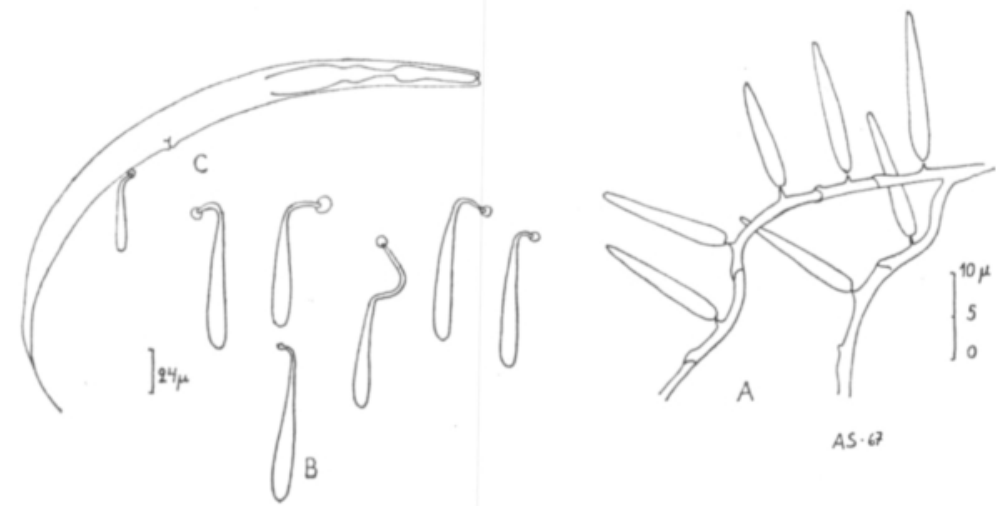

AS.67

Fig. 2. Nematoctonus leiosporus Drechsler. A. Fertile mycelium studded with clamp-connections; B. Conidia with predacious organs; C. Conidia attached to the nematode. 50-day old corn-meal agar culture.

$12.6-22.4 \times 2.2-4.2 \mu$ (Fig. 2, A). Loosened conidia produced at the apex a spurlike, adhesive organ with which the fungus attached itself to the nematode (Fig. $2, \mathrm{~B}-\mathrm{C})$.

Sa. Mäntyharju 1.

The fungus, found in the U.S.A. from leaf mould, destroys e.g. species belonging to the genera: Plectus, Rhabditis, and Wilsonema (Drechsler 1941).

Cephalosporium balanoides Drechsler, Phytopath. 31: 786-787, 1941.

The fungus was established only from the specimens taken from nutrient agar. No aerial hyphae were observed. On the other hand, the dead nematodes grew mycelium (Fig. 3, A) in which the short phialides bore conidia clusters. The endozoic mycelium inside the destroyed host animal was septate, $0.8-2.0 \mu$ in diam. On the outside, the fertile, creeping mycelium produced phialid-shaped conidiophores; they were usually erect, bottle-shaped, $4.8-5.6 \times 1.6-2.8 \mu$ (Fig. 3, B-C). Sterigmata, about $2 \mu$ in length, had formed at their tips or sides. They bore spherical clusters consisting of 5-15 conidia, which were unicellular, truncate cone-shaped, rounded at the edges, $1.6-2.4 \times 1.5-1.9 \mu$ (Fig. $3, \mathrm{D}$ ).

Sa. Mäntyharju 3.

This fungus was first discovered in the U.S.A. in 1938, in leaf mould samples (DRECHSLER 1941). In Europe its occurrence was established about ten years later when Duddington (1951) isolated it from the leaf mould of Betula pubescens. In Sweden, at Alnarp, the fungus was found in 1962 in garden mould (P̈̈ÄSUKE 1962). According to DrECHSLER (1941) the fungus destroys e.g. nematode species of Plectus parvus and Acrobeloides biutschlii. 


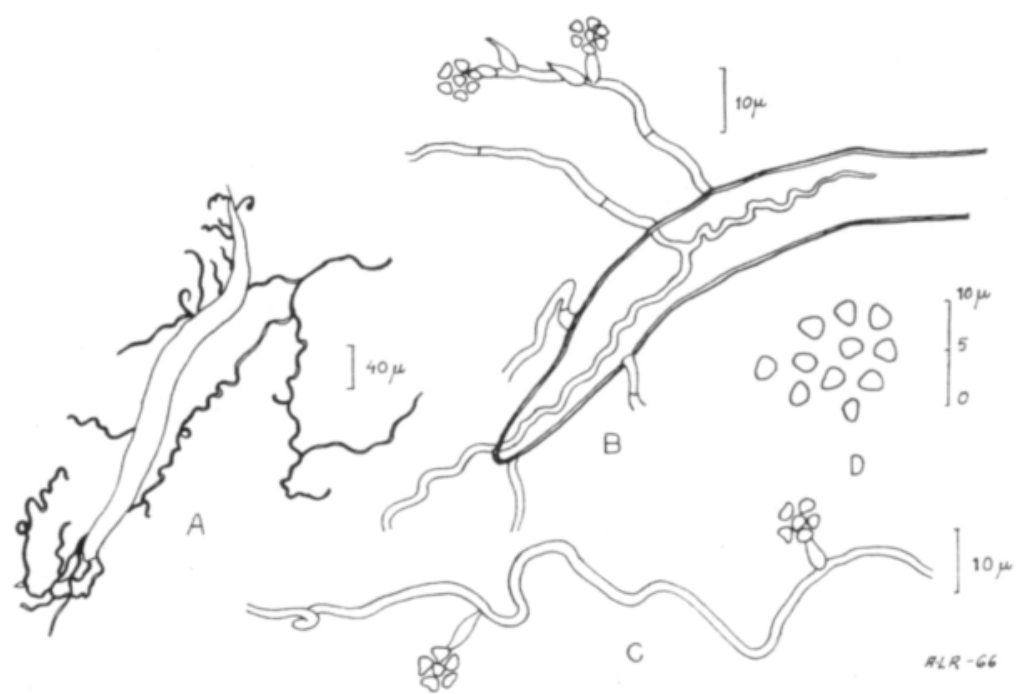

Fig. 3. Cephalosporium balanoides Drechsler. A. Fungus-destroyed nematode; B-C. Fertile hyphae growing from the endozoic mycelium; D. Conidia. 45-day old Czapekś agar (glucose $0.5 \%$ ) culture.

Harposporium lilliputanum Dixon, Trans. Brit. Mycol. Soc. 35: 146-147, 1952.

The fungal mycelium was not observable on the surface of nutrient agar, but closer observation of the hyphae in agar revealed in the neighbourhood of dead nematodes, slender, curved conidia, characteristic of the genus Harposporium Lohde.

In these nematodes an endozoic mycelium was noticed (Fig. 4), which was septate, hyaline or often greenish yellow, $5.0-6.5 \mu$ in diam. The delicate hyphae, which

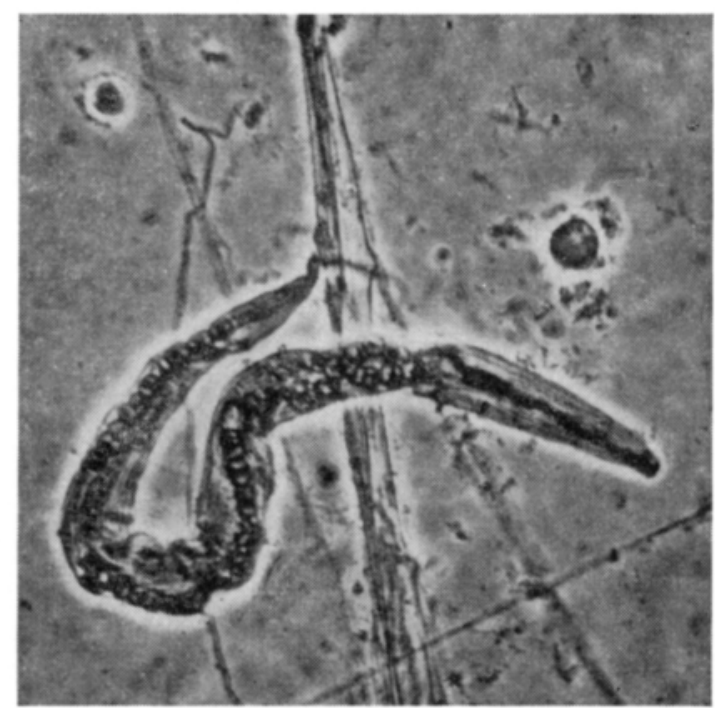

Fig. 4. Endozoic mycelium inside a nematode, destroyed by Harposporium lilliputanum. 


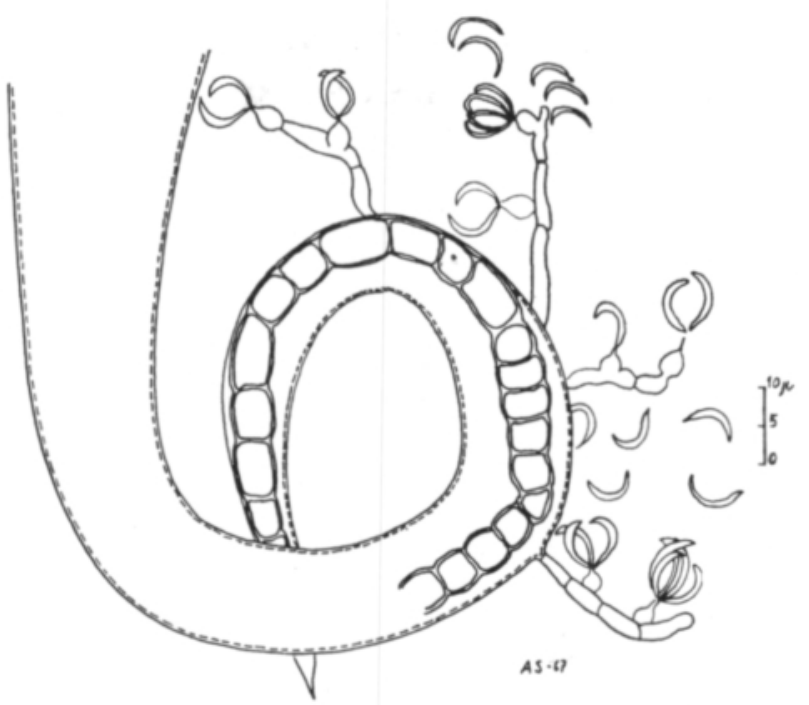

Fig. 5. Harposporium lilliputanum Dixon. Fertile hyphae with conidiophores and conidia growing from fungus-destroyed nematode. 45-day old Czapek's agar (glucose $0.5 \%$ ) culture.

extruded from the nematodes, bore short, subspherical phialides, whose very thin distal necks bore up to 8 arcuate conidia, 5.6-11.2 $\times 0.8-1.6 \mu$ (Fig. 5).

Sa. Mäntyharju 2. - Sb. Pielavesi 1.

H. lilliputanum was first isolated by Dixon (1952) in 1950, in England, from dead nematodes appearing on agar mediums inoculated with shavings of decayed wood. Later its occurrence has been established only by SHEPHERD (1956), who found it in 1952 from beech-tree leaf mould collected in Denmark.

Harposporium oxycoracum Drechsler, Phytopath. 31: 796-797, 1941.

Occurrence of the fungus on the surface of nutrient medium was not observed.

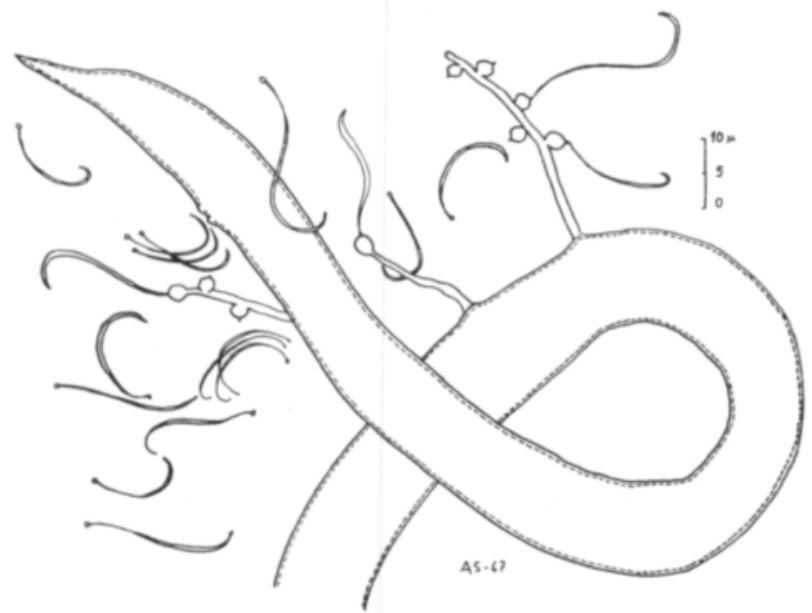

Fig. 6. Harposporium oxycoracum Drechsler. Fertile hyphae with conidiophores and conidia growing from fungus-destroyed nematode. 45-day old corn-meal agar culture. 
On the other hand, in the specimens taken from the nutrient agar, slender, hook-like conidia, characteristic of the genus Harposporium Lohde were established around dead nematodes. Closer inspection of the nematodes revealed an endozoic mycelium, which protruded as fertile hyphae, bearing subspherical phialides, $3.5-4.5 \mu$ in diam. Unicellular, hook-like conidia, $11.5-35.0 \times 0.7-2.8 \mu$ had formed at the necks of the phialides (Fig. 6). The adhesive organ of the fungus appeared to be a viscous, spherical knob at the proximal end of the conidia.

Sa. Joutseno 1.

Regarding the occurrence of H. oxycoracum scant reports exist in the literature. Drechsler (1941) has isolated it from soil in the U.S.A., as well as Duddington (1951) in England. In addition, Drechsler has established that the fungus is destructive to nematodes belonging to the genera: Plectus, Wilsonema and Bunonema.

Arthrobotrys superba Corda, Prachtflora, p. 43, 1839.

A. superba was discovered the conidiophores arising erect from the hyphae and forming terminal conidia. The submerged mycelium of the fungus was septate, $2.1-4.9 \mu$ in diam. The hyphae carried an abundance of adhesive hyphal networks

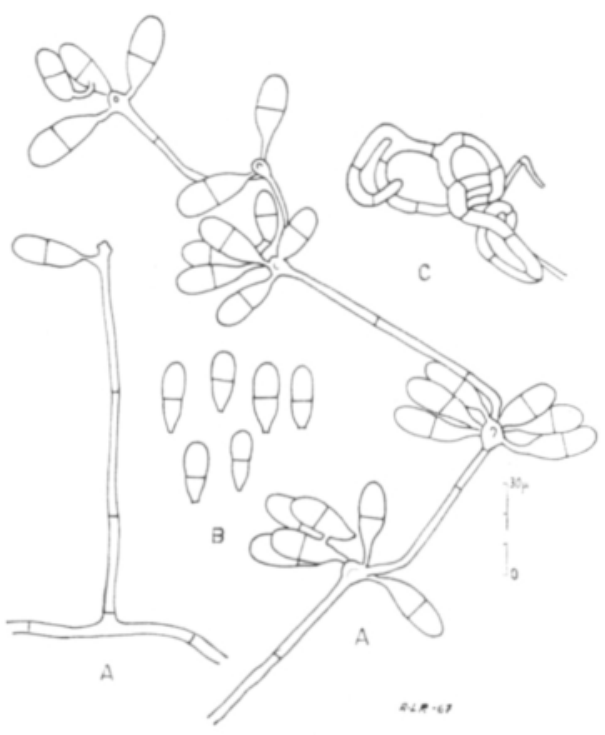

Fig. 7. Arthrobotrys superba Corda. A-B. Conidiophores and conidia from 14-day old pure culture of rice agar; C. Predacious apparatus from 45-day old Czapekś agar (glucose $0.5 \%$ ) culture.
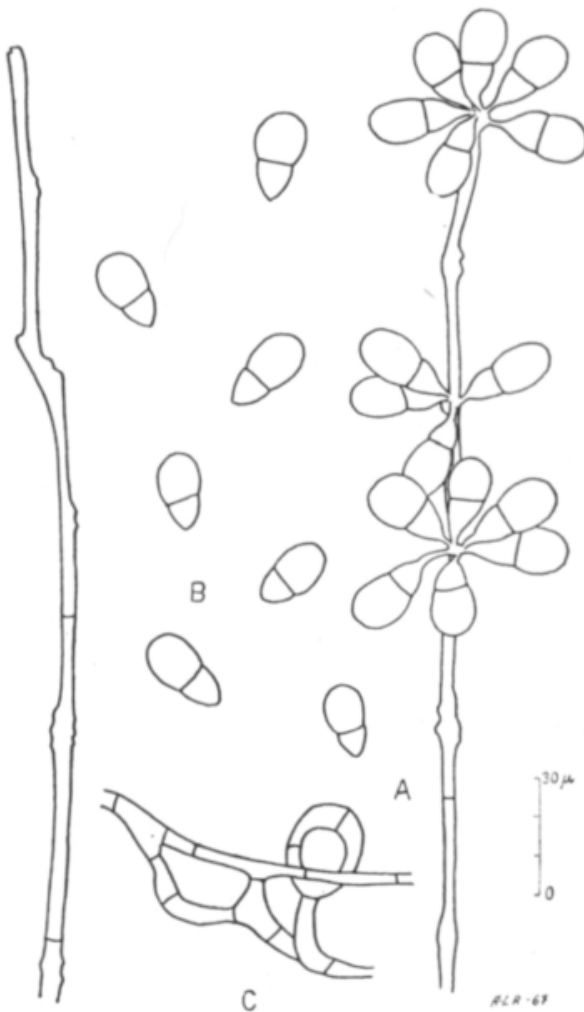

Fig. 8. Arthrobotrys oligospora Fres. A-B. Conidiophores and conidia from 14-day old pure culture of rice agar; C. Predacious apparatus from 40-day old Czapekś agar (glucose $0.5 \%$ ) culture. 
for the purpose of capturing nematodes (Fig. 7, C). The conidiophores (Fig. 7, A-B), measured mostly $200-360 \mu$ in length and were $4.2-5.6 \mu$ in diam. at the base. They were slender, septate, either single or branched. On the stubby sterigmata at the slightly expanding tips of the conidiophores 4-10 conidia developed in curling clusters. The conidia were elongate-obovoid or ellipsoidal, with one septum, 16.8 $26.6 \times 5.6-10.5 \mu$.

In pure culture on rice agar the mycelium was pale pink, scanty in the centre and tufty along the edges.

Ta. Jaala 2; Loppi 2; Nastola 2. - Sa. Imatra 1; Joutseno 8; Luumäki 2. - Kb. Kitee 1. - Sb. Keitele 2. - St. Kankaanpää 1.

The above is in agreement with the description of $A$. superba given by CoRDA (1839) and DREChSLER (1937). The latter recognized nematode-destroying ability of the fungus. In 1949 LAmbert et al. observed A. superba in a mushroom compost. The fungus has been found also in Russia, in 1951 (Soprunov \& Galiulina) and in 1958 (Kondakova), as well as in England, in 1954 (РeAch). In Finland, Salonen (1965) has isolated this fungus from the seed of red clover.

Arthrobotrys oligospora Fres., Beitr. Mycol. Heft 1-2: 1-80, 1852.

A. oligospora produced on the medium an abundance of conidiophores, which were easily perceptible. The vegetative mycelium of the fungus was submerged and septate containing adhesive hyphal networks for the purpose of destroying nematodes (Fig. 8, C). The conidiophores arose from the hyphae erect, septate, mostly 400 $500 \mu$ in length; the conidia which were obovoid, bicellular, $19.6-30.1 \times 9.1-14.3 \mu$, formed grape-like clusters on the sterigmata on the swollen nodes of the conidiophores (Fig. 8, A-B).

In pure culture on rice agar the fungus produced on mycelium abundant conidia clusters. The mycelium was scanty, slightly reddish; the culture had turned pink.

Ta. Jaala 4. - Sa. Joutseno 3; Mäntyharju 10. - Sb. Pielavesi 1. - St. Kiikoinen 1 .

In Germany Fresenius had isolated and described A. oligospora already in 1852. Later Drechsler (1937) has completed the description. The nematodecapturing ability of the fungus was first established by ZopF in 1888. In 1929 KorAB observed that it was destructive to cysts of the sugar beet nematode Heterodera schachtii (in Russia). According to Olthof \& Estey (1963 b) the secretions of A. oligospora may paralyse or kill nematodes.

The fungus has been isolated in several European countries, e.g. in France (Deschiens 1939), in England (Duddington 1950; Peach 1954), in Russia (Korab 1929; Soprunov \& Galiulina 1951), in Denmark (Shepherd 1956) and in Sweden (PÄÄSUKE 1962). In the U.S.A., in addition to Drechsler, data on this fungi have been given by DE WOLFE et al. (1954 a).

Arthrobotrys dactyloides Drechsler, Mycol. 29: 482-487, 1937.

A. dactyloides, like the fungi presented above was also established from the conidiophores arising from nutrient agar. The vegetative mycelium was septate, $2-5 \mu$ in diam. and grew mostly below the surface of the nutrient agar. In addition, 
the mycelium was bearing stalked rings; each ring consisting of three arcuate cells, $20-32 \mu$ in diam. In many cases, the nematodes were captured and constricted by the swollen cells of a ring (Fig. 9, C-D), with assimilative hyphae pushed into the body of the nematode. The conidiophores were septate, erect, $150-400 \mu$ in length, $2.8-5.0 \mu$ at the base and at the tip 2.5-3.0 $\mu$ in diam.; short sterigmata bearing $4-13$ conidia in loose whorls were attached to the tips. The conidia were elongateellipsoidal, straight or slightly curved, 2-celled, 36.4-51.1 $\times 5.6-8.4 \mu$ (Fig. 9, A-B).
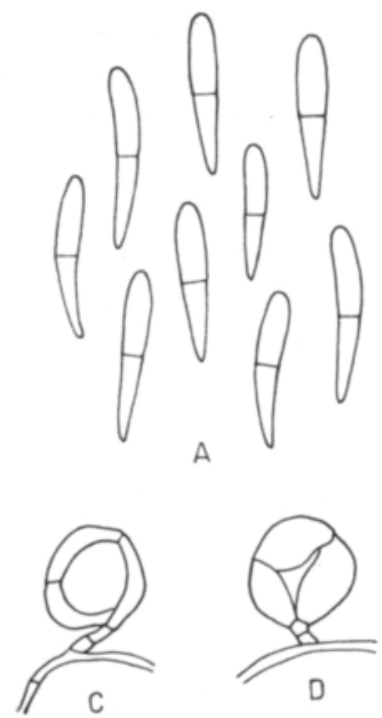

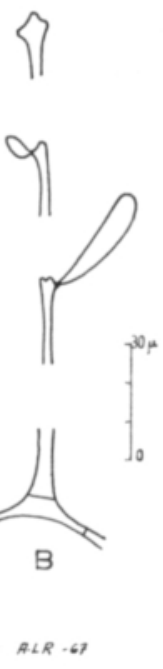

Fig. 9. Arthrobotrys dactyloides Drechsler. A-B. Conidia with both basal and distal structures of the conidiophores; C-D. Predacious constricting rings. 40-day old Czapekś agar (glucose $0.5 \%$ ) culture.

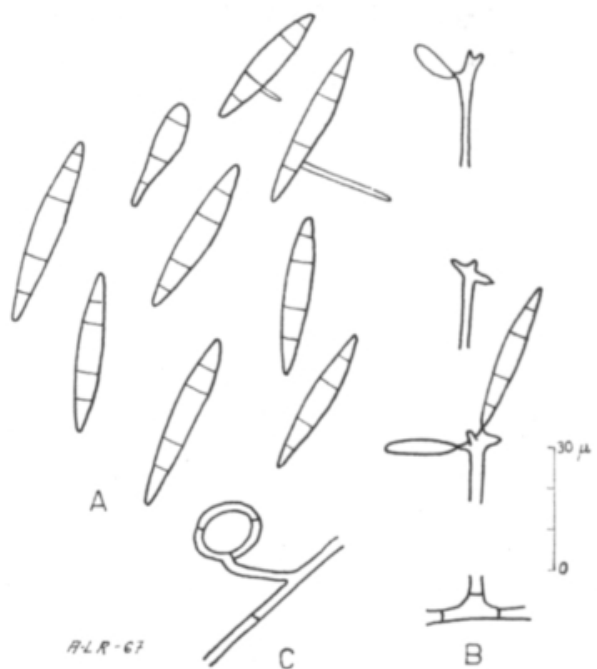

Fig. 10. Dactylaria candida (Nees) Sacc. A-B. Conidia with both basal and distal structures of the conidiophores; C. Predacious non-constricting ring. 30-day old corn-meal agar culture.

Sa. Joutseno 1; Mäntyharju 3.

A. dactyloides was first discovered in 1937, in the U.S.A., in leaf and root debris and in leaf mould in deciduous woods (DRECHSLER 1937). In Europe the fungus has been isolated by SHEPHERD (1956) from soil samples collected in Denmark and by PäÄsukE (1962) from garden mould at Alnarp, Sweden. In 1954 the fungus was recognized in California in a citrus-orchard and was found to be destructive to the citrus-nematode (Tylenchus semipenetrans) (DE WOLFE et al. $1954 \mathrm{a}$ ).

Dactylaria candida (Nees) Sacc., System der Pilze und Schwemme, 1817.

D. candida was established from the conidiophores arising from nutrient agar. The mycelium was submerged, septate, usually $2-6 \mu$ in diam. On these hyphae was formed the predacious apparatus consisting of non-constricting rings, $20 \mu$ in diam., composed of 3 arcuate cells (Fig. 10, C). The conidiophores were single, septate, $150-300 \mu$ in length, bearing at their tip on short sterigmata $5-6$ conidia in a handsome, loose whorl; the conidia were fusiform, $3-5$ septate, $28.0-46.2 \times 5.6-9.1 \mu$ (Fig. 10, A-B). 
Sa. Mäntyharju 2.

NeEs found the fungus in 1817 in a decaying oak stump in Germany. DrechsLER (1937) had recognized it in the U.S.A. and PEACH (1950) in England. LINFORD and YAP (1939) have investigated the significance of D. candida in biological control.

Dactylella brochopaga Drechsler, Mycol. 29: 514-518, 1937.

Conidiophores arising from submerged hyphae and bearing terminal conidia led to the discovery of $D$. brochopaga. The vegetative mycelium was septate, $1.7-4.5 \mu$ in diam., bearing constricting rings, $20-35 \mu$ in diam., consisting of a three-celled ring and the two-celled stalk (Fig. 11, C). The conidiophores were septate, 320$460 \mu$ in length; $5.6-6.3 \mu$ in diam., at the base and $2.8 \mu$ at the tip, which bore $2-12$ short, stubby sterigmata, $2.8-5.6 \mu$ in length; to these were attached $5-10$ conidia forming an irregular whorl. The conidia were curved, cylindrical to elongate-ellipsoidal, distally rounded, $2-4$ celled, $32.2-40.6 \times 4.5-6.6 \mu$ (Fig. 11, A-B).

Sa. Luumäki 2; Joutseno 6; Mäntyharju 7.

DRECHSLER found this Fungi imperfecti-fungus in 1937 in the U.S.A. from leaf mould. Almost 20 years passed before it was again discovered in the U.S.A., this time in a citrus-orchard in California (DE WoLfE et al. $1954 \mathrm{~b}$ ).

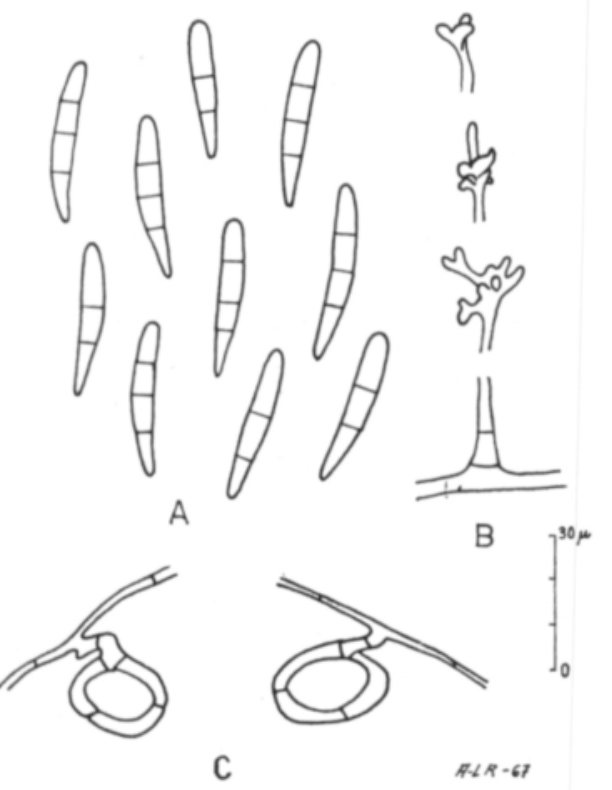

Fig. 11. Dactylella brochopaga Drechsler. A-B. Conidia with both basal and distal structures of the conidiophores; C. Predacious constricting rings. 40-day old Czapekś agar (glucose $0.5 \%$ ) culture.

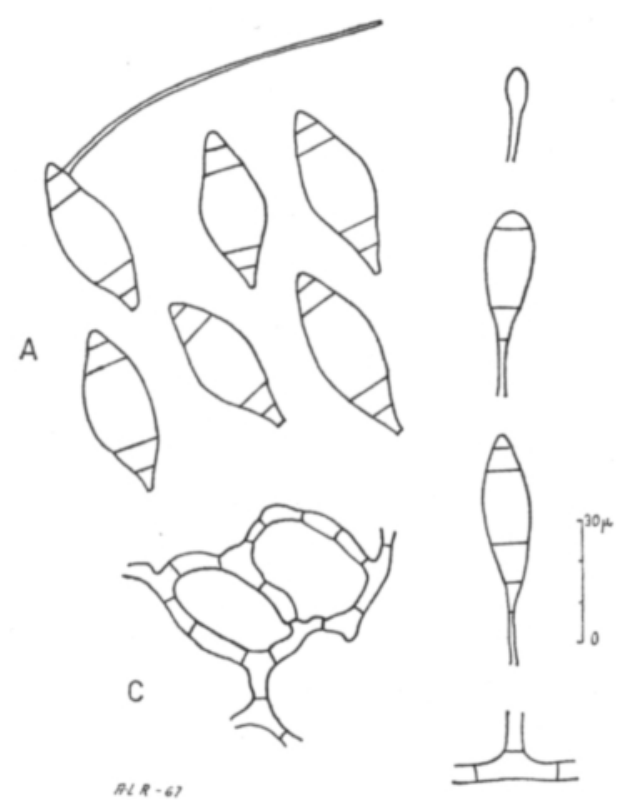

B

Fig. 12. Dactylella gephyropaga Drechsler. A-B. Conidia with both basal and distal structures of the conidiophores; C. Predacious hyphal chain. 30-day old corn-meal agar culture. 
Elsewhere the fungus has been recorded by Soprunov and Galiulina (1951) in Turkmenistan (USSR), and PEACH (1954) in England. According to DrechSLeR (1937), D. brochopaga even traps nematodes $6 \mathrm{~mm}$. in length, e.g. species, belonging to the genera: Acrobeles, Acrobeloides, Cephalobus, Diplogaster, Plectus, Rhabditis and Mononchus.

Dactylella gephyropaga Drechsler, Mycol. 29: 508-513, 1937.

As $D$. gephyropaga formed relatively few conidiophores on the surface of nutrient agar, it was not easy to observe. The fungal vegetative mycelium was septate, $2-5 \mu$ in diam., submerged and often giving rise at short intervals to adhesive columnar branches which later, when $10-30 \mu$ in length, turned to grow parallel to the parent filament forming almost rectangle-like chains of hyphae for the purpose of nematode-capturing (Fig. 12, C). The conidiophores, arose erect from the vegetative mycelium and bore at their tips usually a single conidium. The conidia were top-shaped, slightly rounded at the distal end, truncate at the base, sometimes 2-, usually 3 -4-septate, $30.8-54.6 \times 11.2-21.0 \mu$ (Fig. 12, A-B).

Ta. Jaala 1. - Sa. Imatra 1.

DRECHSLER (1937) observed the fungus in plant debris and leaf mould in the U.S.A. recognizing, moreover, it as destructive to the Acrobeles, Acrobeloides, Cephalobus, Diplogaster, Diploscapter, Plectus and Rhabditis nematode species. Later DE WoLFE et al. (1954 b) established its appearance in California in a citrus-grove and observed it capturing the larvae of Tylenchus semipenetrans. OlthoF and Estey (1963 a) recognized that of four of predacious fungi only $D$. gephyropaga gave significant control of rootknot nematodes (Meloidogyne sp.).

\section{S $u m m a r y$}

In the investigation concerning the microflora of 60 samples, collected from the "saunas" (bath house) from various parts of Finland, and consisting of shavings from the floors and platforms with benches, it was established that many of the samples were infected by nematodes; nematode-destroying fungus species, belonging to Fungi imperfecti were established simultaneously. Of these, Arthrobotrys superba has been previously reported in Finnish literature; new in Finland are the following ten fungi: Nematoctonus concurrens, N. leiosporus, Cephalosporium balanoides, Harposporium lilliputanum, $H$. oxycoracum, Dactylaria candida, Arthrobotrys oligospora, A. dactyloides, Dactylella brochopaga and D. gephyropaga.

\section{REFERENCES}

Corda, A. 1839. Pracht-Flora europaeischer Schimmelbildungen.

Deschiens, R. 1939. Capture et destruction de larves de Strongylidés du singe et du bœuf par des $H y p h o-$ mycètes. [The capture and destruction of Strongylid larvae of the monkey and ox by Hyphomycetes.] Bull. Soc. Path. exot. 32: 394-398. (Ref. Rev. Appl. Mycol. 18: 675.)

Dixon, S. M. 1952. Predacious fungi from rotten wood. Trans. Brit. Mycol. Soc. 35: 146-147. 
Drechsler, C. 1937. Some Hyphomycetes that prey on free-living terricolous nematodes. Mycol. 29: 447 -552 .

- 1941. Some Hyphomycetes parasitic on free-living terricolous nematodes. Phytopath. $31: 773$ -802 .

- 1949. A nematode-capturing fungus with anastomosing clamp-bearing hyphae. Mycol. 41: 369 -387 .

Duddington, C. L. 1950. Fungi that trap eelworms. Bull. Mushroom Grs'Ass. 20: 119-196. (Ref. Rev. Appl. Mycol. 29: 618.)

-1951 . Further records of British predacious fungi II. Trans. Brit. Mycol. Soc. 34: $194-209$.

Duthoit, C. M. G. \& Godfrey, B. E. S. 1963. Effect of green manure and predacious fungi on cereal root eelworm in oats. Plant Path. 12: 18-19.

Fresenrus, G. 1852. Beiträge zur Mykologie. Heft 1-2: 1-80.

Kondakova, E. J. 1958. Predacious fungi in the Moscow suburb. Proc. Lenin Acad. Agric. Sci. 23: 28-33. (Ref. Rev. Appl. Mycol. 37: 445.)

Korab, I. I. 1929. Results of a study of the beet nematode Heterodera schachtii Schm. according to investigations carried out at the nematode laboratory at Belozerkovsk. Ukrainian Research Institute for the sugar industry, Kiev 8,16: 29-67. (Ref. Drechsler, C. 1937.)

Lambert, E. B., Steiner, G. \& Drechsler, C. 1949. The "Cephalothecium diseasen of cultivated mushrooms caused by a nematode (Ditylenchus sp.), evidenced by surface development of predacious fungi. Plant Dis. Rep. 33: 252-253.

LINFORD, M. B. \& YAP, F. 1939. Root-knot nematodes injury restricted by a fungus. Phytopath. 29: 596-609.

Nees von Esenbeck, C. G. 1817. Das System der Pilze und Schwämme.

Olthof, T. H. A. \& Estey, R. H. 1963 a. Nematode-trapping fungi and rootknot of tomato. Forty third report of the Quebec Society for the protection of plants 1961 . 79 p. (Ref. Rev. Appl. Mycol. 43: 337.)

- - \& Estey, R. H. 1963 b. A nematotoxin produce by the nematophagous fungus Arthrobotrys oligospora Fresenius. Nature 197: 514-515. London.

Peach, M. 1950. Aquatic predacious fungi. Trans. Brit. Mycol. Soc. 33: 148-153.

-1954 . Aquatic predacious fungi III. Ibid. $37: 240-247$.

PĀÃsUKE, M. 1962. Preliminary report on control of Pratylenchus penetrans by predacious fungi. Acta Agric. Scand. 12: 135-147.

SALONEN, A. 1965. Puna-apilan siemenlevintäisistă sienistä Suomessa. Manuscript 167 p. [Available at Department of Plant Pathology, Helsinki, Finland.]

ShePHerd, A. M. 1956. A short survey of Danish nematophagous fungi. Friesia 5: 396-408.

Soprunov, F. F. \& Galiulina, Z. A. 1951. Predacious Hyphomycetes from Turkmenistan soil. Microbiol. 20: 489-499. (Ref. Rev. Appl. Mycol. 32: 125.)

- - \& Tendetnik, Y. Y. 1960. Data on the practical use of predacious fungi for the control of some eelworm diseases. Trud. gel'minst. Lab. 10: 192-194. (Ref. Rev. Appl. Mycol. 40: 454.)

De Wolfe, T. A., Klotz, L. J., Baines, R. C. \& Moore, P. W. 1954 a. Nematode capturing fungi. Calif. Citrogr. 39: 104. (Ref. Rev. Appl. Mycol. 34: 647.)

- Klotz, L. J., Moore, P. W. \& Hashimoto, S. 1954 b. Effects of mulches on citrus orchards. Ibid. 39: 423, 436-437. (Ref. Rev. Appl. Mycol. 34: 781.)

ZopF, W. 1888. Zur Kenntniss der Infections-Krankheiten neiderer Thiere und Pflanzen. Nova Acta Leop.-Carol. Deut. Acad. Naturf. 52: 314-376. 


\title{
SELOSTUS:
}

\section{NEMATODEJA TUHOAVISTA SIENISTÅ SUOMESSA}

\author{
Anna-Lisa Ruokola ja Arvi Salonen \\ Yliopiston kasvipatologian laitos, Helsinki
}

Eri puolilta Suomea saunoista kerättyjen näytteiden, puulastuja lattialta ja lauteilta, mikrofloraa tutkittaessa todettiin niistă monet nematodien saastuttamiksi ja samalla niissä havaittiin ankeroisia tuhoavia Fungi imperfecti-sieniä. Näistä Arthrobotrys superba on aikaisemmin mainittu kirjallisuudessamme; maallemme uusia ovat seuraavat 10 sientä: Nematoctonus concurrens, $N$. leiosporus, dephalosporium balanoides, Harposporium lilliputanum, $H$. oxycoracum, Avthrobotrys oligospora, A. Cactyloides, Dactylaria candida, Dactylella brochopaga ja D. gephyropaga. 